\title{
Environmental Management in Joint Streams Regulation by two Hydroelectric Complexes
}

\author{
Balzannikov M.I., Mikhasek A.A., Yurov V.M. \\ Samara State Technical University, Institute of Architecture and Civil Engineering \\ Address: Molodogvardeyskaya St., 194, Samara, 443001, Russia
}

\begin{abstract}
Lowland river water power developments are usually built to solve complex tasks on the basis of the requirements of rational use of water resources. First of all, operating conditions of hydroelectric complex structures should provide safety and economic efficiency in their work. Besides, they are aimed to satisfy various demands of water consumers. It is particularly important that behaviour of hydroelectric complex structures should satisfy contemporary requirements of environmental security.

The most important task here is to create favourable ecological conditions of life for people who live in settlements located in the zone of influence of two hydroelectric complexes located on different rivers. Here, to achieve environmental targets it is necessary to interlink modes of operation of these water storage control structures.

There are two water power developments built in the Republic of Bashkortostan, Russia, in the middle flow of the Belaya River. Both of them have considerable impact on the formation of level mode and different consumers' water supply. They are Umaguzinskiy and Nugushskiy water power developments.

Both hydroelectric complexes and their water reservoirs together satisfy the following generally accepted requirements of water consumers:

- they prevent the lowering of the water level in the river Belaya (during low streamflow period) below the minimum values required to ensure proper water supply for industrial enterprises;

- they generate electric power and provide industries and cities with electricity. To do that each water-economic complex has its own water reservoir and a set of retaining structures and required culvert installations.

In addition, the following environmental requirements are imposed on co-regulation of water runoff:

- protection of waterfronts of the towns Meleuz, Salavat, Ishimbay and Sterlitamak from flooding in flood season;

- protection of the territories of refineries in flood season (during water rise).

Umaguzinskiy water power development has the following water sluices to control water stream: 1) submerged flooddischarge outlet; 2) shore flood spillway; 3) aggregates of powerhouse. General water carrying capacity of hydroelectric complex structures is $3915 \mathrm{~m}^{3} / \mathrm{c}$. Nugushskiy hydroelectric complex consists of hydraulic engineering structure power room (1) and left shore spillway (2). Combined water carrying capacity of all hydroelectric complex structures here is $1250 \mathrm{~m}^{3} / \mathrm{c}$.

The authors investigated operation modes of Nugushskiy and Umaguzinskiy water power developments when linked into one water-economic complex and came to the conclusion that modes of operation of these water storage control structures should be adjusted in accordance with the operational condition of the main pressure installations and of downstream flood-control facilities. In particular, it is necessary to take into account the unfinished state of flood prevention measures in the middle reaches of the river Belaya.
\end{abstract}

Keywords: hydroelectric complex, water reservoir, culvert, flow regulation, water level, ecological safety.

\section{INTRODUCTION}

Thee are many rivers with high hydroelectric potential in the Russian Federation (see Table 1). This potential is mostly realized in the Central Plains of the country [1, 2]. Lowland river water power developments are usually built to solve complex tasks on the basis of the requirements of rational use of water resources. First of all, operating conditions of hydroelectric complex structures should provide safety and economical efficiency in their work. Besides, they are aimed to satisfy various demands of water consumers $[3,4,5,6,7]$. It is also very important that the behaviour of hydroelectric complex structures should meet modern requirements of environmental safety $[8,9,10,11,12]$.

Rules of water resources use are usually developed for each particular hydroelectric complex and are applied to a standard operational period. These rules provide detailed characteristics of this certain reservoir and its capabilities, the main watercourse of the river settings, composition and description of retaining and culvert constructions of hydro-unit security requirements in the upper and lower ponds of waterworks, characteristics of water users and water 
consumption, detailed regulation of runoff and reservoir operation regime for different periods of the year as well as different amounts of water in a flood, a list of necessary activities during flood season, etc. [13].

Table I

Hydropower resources of the rivers of the Russian Federation [1]

\begin{tabular}{|l|c|}
\hline \multicolumn{1}{|c|}{ River } & $\begin{array}{c}\text { Energy potential, bln. } \\
\text { kW-h }\end{array}$ \\
\hline The Enisey & 158.3 \\
\hline The Lena & 144.0 \\
\hline The Angara & 93.9 \\
\hline The Amur & 82.9 \\
\hline The Volga & 54.3 \\
\hline The Ob & 51.4 \\
\hline The Vitim & 50.7 \\
\hline The Nizhnyaya & 41.0 \\
Tunguska & 39.8 \\
\hline The Kolyma & 39.6 \\
\hline The Indigirka & 31.0 \\
\hline The Katun & 25.2 \\
\hline The Irtysh & 22.5 \\
\hline The Vilyuy & 18.0 \\
\hline The Podkamennaya & 17.4 \\
\hline Tunguska & 15.2 \\
\hline The Zeya & 14.6 \\
\hline The Tom & 12.7 \\
\hline The Bureya & 12.3 \\
\hline The Kama & 11.0 \\
\hline The Pechora & 10.9 \\
\hline The Oka & 10.7 \\
\hline The Terek & 10.2 \\
\hline The Kuban & \\
\hline The Anadyr & \\
\hline
\end{tabular}

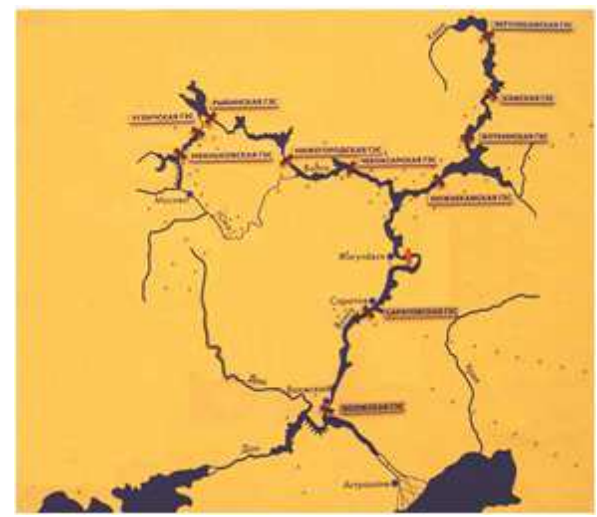

Fig. 1. Diagram of the Volga-Kama cascade of hydroelectric power stations

Such rules are widely recognized for particular hydroelectric complexes that operate independently from other installations. However, there are a lot of rivers in the country with a whole cascade of hydroelectric facilities on them. For example, the most famous and significant largest cascade in respect to its catchment-basin and total capacity of hydroelectric power plants is the Volga-Kama cascade of HPS (see Figure 1). Here the task of rational distribution of water resources is quite complex because controlling of one reservoir must be linked to conditions and work of related reservoirs located both upstream and downstream [14, 15].

Even more challenging is the management of water resources which are not consistently located in a cascade not one after another, but are waterworks built on different rivers which merge together into one river downstream.

Such reservoirs are replenished from different catchment basins, whchi as a rule have different characteristics. Therefore, when joint management regimes of reservoirs is used, it is extremely important to forecast runoff during periods of high water [16]. Even more important is the task of creating favourable ecological conditions of life of the population in the settlements which territory is located in the zone of influence of overall joint afterbay of such hydroelectric complexes.

\section{MATERIALS AND METHODS}

There are two water power developments: Umaguzinskiy and Nugushskiy in the Republic of Bashkortostan, Russia, in the middle flow of the Belaya River. Both hydroelectric complexes as well as their water reservoirs are located on the territory of the Bashkir National Park (see Figure 2).

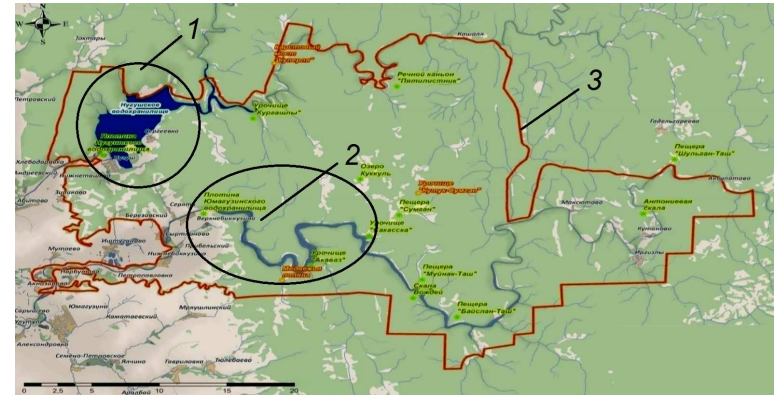

Fig. 2. Umaguzinskiy and Nugushskiy water power developments located on the territory of the National Park "Bashkiriya" 1 Nugushskiy water power development and its reservoir; 2 Umaguzinskiy water power development and its reservoir; 3 - the boundary of the National Park

In this context, great importance in determining the operational mode of hydropower work of meeting the objectives of the regulation of the flow is given to ensuring environmental safety requirements. The leading position here lies with the preservation of acceptable water-levels on the territory of the lower afterbay, which for these units is a joint afterbay.

Nugushskiy water power development (the first of the two) was being built from 1961 to 1967 . Its water storage basin has useful storage capacity of $365 \mathrm{ml}$ $\mathrm{m}^{3}$. This water power development consists of the following water-retaining structures and culverts: the phreatic dam, the hydraulic engineering structure power room (run-of-river-type with three hydraulic turbines), left shore concrete spillway (see Figure 3).

Combined water carrying capacity of all hydroelectric complex structures here is $1250 \mathrm{~m}^{3} / \mathrm{c}$. 


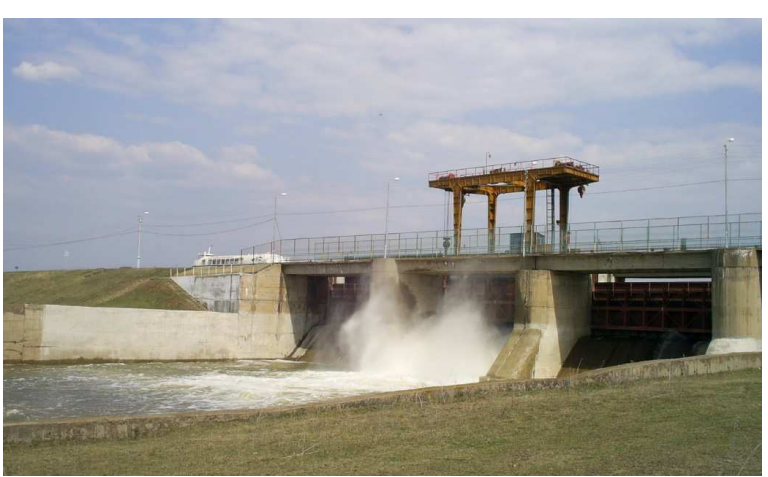

Fig. 3. Water flow through the supercharger dam of Nugushskiy water power development [13]

The research consisted of field studies of hydroelectric complexes operating modes, of the state of the structures, of coming water discharge in the reservoir and passing water discharge to lower afterbay. The tests also included measurements of water levels in the reservoir and other parameters. The researchers recorded water levels in the downstream near to residential settlements and industrial enterprises. Figure 4 shows examples of changes in water level in the reservoir for different hydroeconomic years (starting in March).

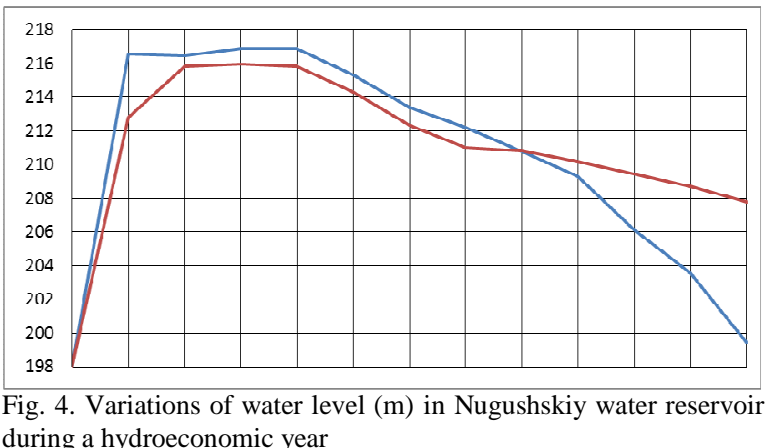

Observation yielded the following results: The reservoir of Nugushskiy water power development was filled in full. During seasonal flood considerable water amount was discharged into the afterbay. This has resulted in the fact that nature protection requirements were not fully fulfilled. In particular, the coastal area around ehe cities of Meleuz, Salavat, Ishimbay and Sterlitamak was not protected from flooding in flood season, as well as the protection of the territories of industrial enterprises in the season of higt water during floods. Moreover, the devastating flood of 1978 and 1990, as well as periods of dry lowwater periods in 1955 and 1975 years caused serious damage to the national economy of the region.

Before the construction of Umaguzinskiy hydroelectric complex in the middle flow of the Belaya River (in the downstream of Nugushskiy hydroelectric complex) the minimal demanded water discharge to maintain the water-level (required for water extraction by industrial enterprises and public water supply) in the low streamflow period was not provided.

Therefore, it was decided to build Umaguzinskiy water power development. The main task of the construction of the reservoir was to build a water reservoir capable to reduce the negative impact of river flow at the objects of national economy (at the expense of the annual flow) and increase water discharge in the after in low-water periods.

\section{RESULTS AND DISCUSSION}

Umaguzinskiy water power development was being built from 2003 to 2007 . It includes a rock-fill dam which is $63 \mathrm{~m}$ height and 605 length and which blocks the river right when it passes the barrows. Figure 5 shows a general view of the dam. The dam formed a headwall and it led to a water reservoir formation with a useful storage capacity of $435 \mathrm{ml} \mathrm{m}^{3}$. The water reservoir was located in a narrow dale (see Figure 6). Hence, it was possible to avoid large area flooding thus minimizing environmental damage [17, 18, 19].

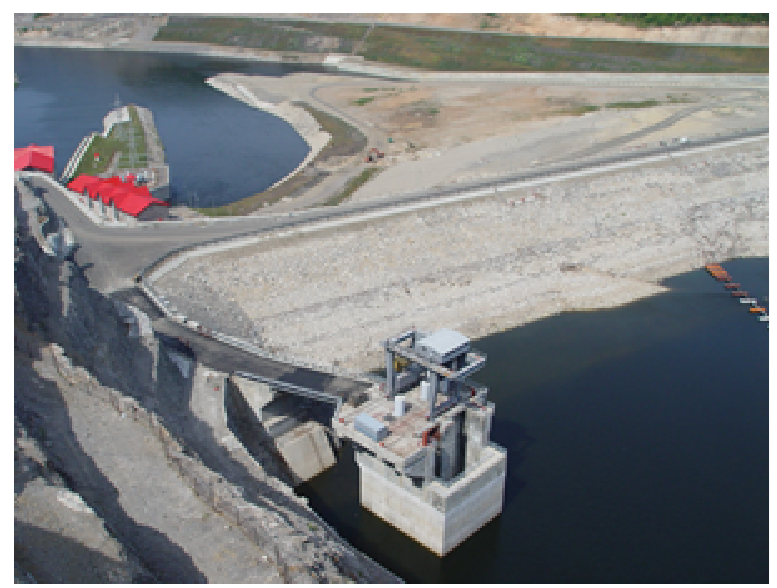

Fig. 5. A view of the dam of Umaguzinskiy hydroelectric complex (photo taken by the author)

Umaguzinskiy water power development has the following water sluices to control water stream: 1) submerged flood-discharge outlet; 2) shore flood spillway; 3) hydroelectric power station powerhouse.

Hydroelectric power station powerhouse is located on the left bank of the dam. It contains three hydraulic turbines have the maximum $130 \mathrm{~m} 3 / \mathrm{c}$ water flow capacity and provide installed capacity of $45 \mathrm{kVt}$ with rated head of $40 \mathrm{~m}$. Its maximal water flow capacity of flood-discharge outlet is $130 \mathrm{~m}^{3} / \mathrm{c}$ and can be reached only in overflow spring flood-time. The water flows through three tunnel pressure turbine passages (with $3.2 \mathrm{~m}$ diameter). 


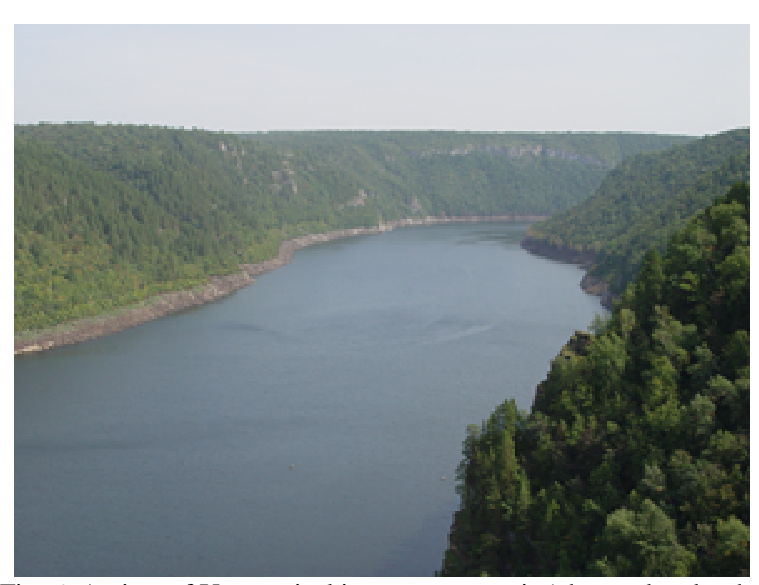

Fig. 6. A view of Umaguzinskiy water reservoir (photo taken by the author)

Into the turbine water passageways, water comes from submerged flood-discharge outlets. The entrance of the tunnel is designed as a portal and is placed at the left bank (see Figure 5). The spillway of tunnel submerged flood-discharge outlet goes through rock masses and ends as a portal outlet containing mechanical equipment. This submerged flooddischarge outlet is used in rare flood periods of low water levels. Its maximal water flow capacity of flood-discharge outlet reaches $1465 \mathrm{~m}^{3} / \mathrm{c}$. Parameters of hydraulic structures were substantiated in accordance with the requirements of generally accepted methods with account of ensuring the reliability of their work $[20,21]$.

After Umaguzinskiy water power development had been constructed, river flow control function was put on both reservoirs. Besides, the following environmental requirements were laid down on the joint use of water resources:

protection of waterfronts of the towns Meleuz, Salavat, Ishimbay and Sterlitamak from flooding in flood season;

protection of the territories of refineries in flood season (during water rise).

In the initial period of Umaguzinskiy water power development operation extra problems in the area of environmental requirements appeared. The thing is that the project involved a comprehensive approach to the protection of the coastal territories of the afterbay. The approach included both flow co-regulation by two hydroelectric complexes and flood control constructions building around the above-mentioned cities. These requirements were taken into account when introducing the rules of Umaguzinskiy reservoir operation. Still, these bank protective structures were not put into operation at that time. In this regard, it was required to make corrections in the rules for the period of completion of flood prevention measures.

It was decided to develop methods of control for modes of the water regulating complex, consisting of two reservoirs and having shared water area of influence in the middle reach of the river Belaya, for operating conditions different from the project.
The task was based on the analysis of conditions under which water consumers of both downstream and upstream sides of hydroelectric complexes could operate in a usual way. The requirements of the above mentioned settlements located in the zone of possible flooding were taken into account, as well as requirements of industrial enterprises, population and agriculture, electricity consumers and fisheries enterprises which suffered from water deficit the lowwater period. The facts that Umaguzinskiy water reservoir is located on the territory of the National Park "Bashkiriya" and longstanding irregularity of the river flow were also taken into account (see Figure 7). The developed method of regulating modes of water reservoir consisting of two reservoirs control included the following stages for the period of floods [16, 23]: 1. Obtaining an official forecast of runoff in the flood period. 2. Defining a similar year. For a similar hydroeconomic year the authors calculated water discharge coefficient $\mathrm{K}$, showing run-off excess in Umaguzinskiy water reservoir above the drain in line of discharge gauging station of Nugushskiy hydroelectric complex. Determination of the average flow rate in the control range of Sterlitamak discharge gauging station. 4. Using the drains coefficient, the forecast of maximum runoff in the flood period for reservoirs was adjusted. 5. Using the table of data for the flood period in the upper and middle reaches of the main watercourse the reserchers identified water discharge and water level mark at the highest point of the upper discharge gauging station (№1). 6. With account of the "travelling wave" $t$ for the lower discharge gouging station (№2) the researchers defined the corresponding water-level. 7. Current information on water levels at gauging stations was taken every day. 8. Water inflow to discharge gauging station №3 was thoroughly counted. 9. The water level on discharge gauging station №3 was measured. 10. With account of the "travelling wave" the researchers measured the afterbay level of Umaguzinskiy hydroelectric complex (№3). 11. According to a certain level of water in the control range of Sterlitamak discharge gauging station the perspective water discharge was defined (for a day ahead). This discharge rate was compared with a possible maximum value allowed by environmental conditions. If the expected discharge exceeded the allowable amount, then corresponding corrections were made for the discharged water coming through Umaguzinskiy hydroelectric complex outlet. Thus, the methodology established the relationship between the natural flow of the upper reaches of the watercourse and the strong flow of the middle reaches of the watercourse in the monitoring section. 


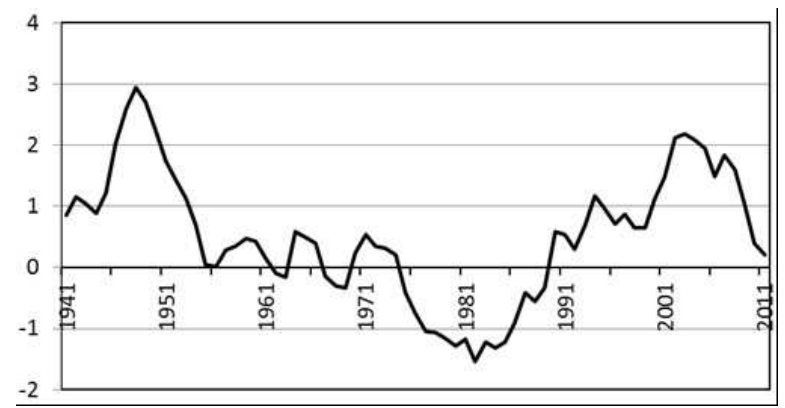

Fig. 7. Differential integral curve in relative values showing the Belaya river runoff in line of Umaguzinskiy reservoir [22]

Analysis of the actual application of this methodology showed that the difference between estimated and actual flood amount at the Umaguzinskiy hydroelectric complex in 2012 did not exceed $4.5 \%$, which demonstrates the high practical relevance of the developed method.

\section{CONCLUSION}

1. A critical requirement when operating hydroelectric complexes and their reservoirs is ensuring environmental security. It is required to carefully analyze conditions of creating favourable environmental regimes for settlements which territory is situated in the zone of influence of two hydroelectric complexes built on different rivers with different characteristics of catchment basins. Working modes of transmission facilities of these hydroelectric complexes should bee mutually linked.

2. For Umaguzinskiy and Nugushskiy water power developments built in the Republic of Bashkortostan, Russia, in the middle flow of the Belaya River ecological requirements are as follows: - protection of waterfronts of the towns Meleuz, Salavat, Ishimbay and Sterlitamak as well as industrial enterprises from flooding in flood season; With the purpose of rational use of water resources of the joint regulating complex and environmental requirements compliance, an advanced methodology for the period of incompleteness of all flood prevention measures has been developed in this research. The use of the proposed methodology has proved its high practical value.

\section{REFERENCES}

[1.] Vasilyev Yu.S., Elistratov V.V. Hydroelectric installations. Published by St Petersburg Polytechnic University. SPb., 2011.

[2.] Elistratov V.V. Renewable energy. SPb.: IZD-vo «Nauka», ed. 2, 2013, 308 p.

[3.] Vasilyev Yu.S., Kubyshkin L.I. The technology design of hydropower facilities. Hydrotechnical construction, 7, 2014, pp. 2-8.

[4.] Balzannikov M.I. , Yurov V.M. , Mikhasek A.A. Pecularities of joint streams regulation by hydroelectric complexes. Scientific Survey, 3, 2015, pp. 101-108.

[5.] Svitala F., Evdokimov S.V., Galitskova Yu.M. Peculiarities of hydraulic structures and aggregate buildings designs of the first hydroelectric plants. Industrial and civil engineering, 12, 2014, pp. 87-90.

[6.] Evdokimov S.V. New construction of power plants based on renewable energy sources ensuring the efficiency and reliability of their work. Industrial and civil engineering, 8, 2010, pp. 35-38.

[7.] Balzannikov M.I., Ivanov B.G., Mikhasek A.A. Control system of hydraulic engineering structures. Vestnik MGSU, 7, 2012, pp. 119-124.

[8.] Balzannikov M.I., Rodionov M.V., Seliverstov V.A.. Increasing the environmental safety of earth hydrotechnical structures. Urban Construction and Architecture, 1, 2011, pp. 100-105.

[9.] Evdokimov S.V., Dormidontova T.V. Evaluation of reliability of hydraulic structures. Urban Construction and Architecture, 1, 2012, pp. 49-53.

[10.] Evdokimov S.V., Dormidontova T.V. Criteria for evaluating the reliability and technical condition of hydrotechnical constructions. Urban Construction and Architecture, 2, 2012, pp. 105-109.

[11.] Balzannikov M.I. Power plants based on renewable energy sources and their impacts on environment. Vestnik Volgogr. st.. archit.-builds. un. Architecture and civil engineering, Vol. 31(50), Part 1, 2013, pp. 336-342.

[12.] Balzannikov M.I., Evdokimov S.V., Galitskova Yu.M. Development of renewable energy as an important contribution to environmental protection. Industrial and civil engineering, 3, 2014, pp. 16-19.

[13.] Balzannikov M.I., Yurov V.M., Mikhasek A.A. On structures and control methods of joint streams regulation by two water power developments in satisfying water consumers' demands. Procedia Engineering, V. 111, 2015, pp. 82-88.

[14.] Elistratov V.V., Maslikov V.I., Sidorenko G.I. Water-power modes of the Volga-Kama cascade of HPP. Hydraulic engineering, 11, 2014, pp 11-15.

[15.] Maslikov V.I., Sidorenko G.I. Analysis of water and energy modes Zhigulevsk hydroelectric power station and connections of electricity with water flow. Urban Construction and Architecture, 2, 2015, pp. 73-80.

[16.] Yurov V.M. Improving management regimes of two reservoirs as a single waterregulating complex (with the river Belaya as an example). Dissertation for a scientific degree of candidate of technical sciences. Samara, SGASU, 2014, 23 p.

[17.] Balzannikov M.I. Reservoirs of energy facilities and their impact on the environment. Energy audit,1, 2007, pp. 32-35.

[18.] Sobol I.S. Pecualarities of long-term dynamics of the shores of small plain reservoirs in the European territory of Russia. Privolzhsky scientific journal, 2, 2013, pp. 65-67.

[19.] Sobol S.V., Fevralev A.V., Sobol I.S., Sidorov N.P. Development of the scheme of complex use and protection of water objects of the Sura river basin. Privolzhsky scientific journal, 4, 2013, pp. 124-129.

[20.] Vasilyev Yu.S., Sidorenko G.I., Frolov V.V. Justification methods for small hydroelectric power station. Scientific and technical statements, St. Petersburg State Polytechnic University, 147-1, 2012, pp. 76-84.

[21.] Balzannikov M.I., Rodionov M.V., Senitskiy Yu.E. Incresing operational reliability of hydroengineering facilities with groundwater dams. Privolzhsky scientific journal, 2, 2012, pp. $35-40$.

[22.] Abdrakhmanov R.F., Tur V.A., Yurov V.M. Jumaguzinskoe reservoir. Formation of hydrological and hydrochemical regimes. Ufa: Informreklama, 2008, 152 p.

[23.] Yurov V.M. Improving control methods of regulating water control complex modes in the middle flow of the river Belaya. Urban Construction and Architecture, 3, 2014, pp. 77-82. 